\title{
Investigation of Teacher Candidates' Competence Perception and Attitude towards Teaching
}

\author{
Erdi KAYA \\ Akdeniz University, Faculty of Sport Sciences, Turkey. \\ Email:kaerdikaya@gmail.com Tel:00903065000140
}

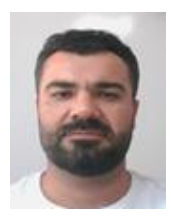

\begin{abstract}
In this research, it was aimed to investigate the self-competence perception and attitudes towards teaching profession of teacher candidates' who study in different universities in terms of universities. It was observed that the level of self-competence perception of the students participating in the study did not differ statistically significantly $(\mathrm{p}>0,05)$, and the attitude levels related to teaching profession differed statistically significantly based on the universities they studied $(\mathrm{p}<0,05)$. The data collected within the research were analyzed using SPSS 22 software. Mann Whitney U test was used to compare scale scores of university students participating in the study according to gender, academic success level and sports activities while Kruskal Wallis H test was used to compare scale scores according to their age groups, universities, departments and income status. According to the results of the study, it was observed that the attitudes of university students participating in the study towards teaching profession and their competence perception levels related to themselves did not differ statistically significantly according to their sports habits. Upon examination of it is observed that the level of self-competence perception of the university students participating in the study did not differ statistically significantly, and their attitude levels related to teaching profession differed statistically significantly based on their income levels. In the attitude towards teaching profession, the attitude level of students with average income levels are statistically significantly higher than the attitude level of students with higher income levels.
\end{abstract}

Keywords: Prospective teachers, Sports, Approach, Competence, Attitude, University

Citation | Erdi KAYA (2019). Investigation of Teacher Candidates' Competence Perception and Attitude towards Teaching. Asian Journal of Education and Training, 5(4): 531-537. History:

Received: 16 July 2019

Revised: 22 August 2019

Accepted: 1 October 2019

Published: 12 November 2019

Licensed: This work is licensed under a Creative Commons

Attribution 3.0 License $(\mathrm{cc})$ EY

Publisher: Asian Online Journal Publishing Group
Funding: This study received no specific financial support.

Competing Interests: The author declares that there are no conflicts of interests regarding the publication of this paper.

Transparency: The author confirms that the manuscript is an honest, Transparency: The author confirms that the manuscript is an honest,
accurate, and transparent account of the study was reported; that no vital features of the study have been omitted; and that any discrepancies from the study as planned have been explained.

Ethical: This study follows all ethical practices during writing.

\section{Contents}

1. Introduction

2. Method 


\section{Contribution of this paper to the literature}

This study contributed to the literature by investigating the self-competence perception and attitudes towards teaching profession of teacher candidates', who study in different universities in terms of universities.

\section{Introduction}

One of the fundamental rights of human beings is education. Education is a development in which humans are within throughout their lives (Atmaca, 2015). In an education system, there are many conditions that affect students' achievement such as student, teacher, curriculum, directors, education experts, educational technology and physical resources (Sişman, 2004). Teachers have the largest share in education and teaching. Contributing to permanence, continuity and development of education depends on the education provided by teachers. Thus, investments made to the share of education in our country should gain importance (Duymaz, 2007). In line with needs of the country, qualified and multidirectional teachers with sufficient levels are needed together with education in order to educate new generations (Küçükahmet, 2003). The teacher being competent in terms of quality and quantity has a direct effect on other individuals educated. Regardless of the field, the teachers working by adding feelings, lovingly and willingly will ensure success in the near future (Sağlam, 2008). Teacher is the person who will help development of the society by processing, interpreting and thus improving knowledge and providing most benefit to students in education by integrating them into the society (Şahin, 2007). Behaviors of the teacher in the classroom is closely related to the attitudes they have. Therefore, attitudes affect behaviors and social perceptions (Kă̆ıtçıbaşı, 2010). As is known, teaching is a profession that requires cognitive domain gains such as knowledge and skills as well as affective domain gains such as attitude and behavior. Teacher candidates' values and attitude competencies related to their profession are at least as necessary as knowledge" (Cetin, 2006). For this reason, the professional attitude of the teacher has an important role in education as well as the professional knowledge (Koyuncu, 2015).

Attitude; can be discussed as a set of emotions that include also some complex situations that a person feels for any object, person, event or case. On the other hand, the professional attitude is related to whether or not persons takes responsibility for their professions and they fulfill the requirements of their profession and it also include some affective features (Koyuncu, 2015). One of the requirements for the persons, who will practise the teaching profession, to be able to fulfill the requirements and competencies of this profession more effectively is that they have positive attitudes towards the profession (Demirtaş et al., 2011). Attitudes affect the person's emotions, thoughts and behaviors. For this reason, regardless of the branch distinction, teachers' attitudes towards their professions have an important place, although it causes them to perform the teaching profession more willingly and wantingly and to be more successful (Celiköz and Cetin, 2004). In the same time, teachers' attitudes towards the profession are reflected in their behaviors and classroom environment and it has a significant role in the personality development of the students, the feature of teacher-student relations and the realization of learning (Semerci and Semerci, 2004).

Continuous self-development as well as disciplined and devoted work are important factors in teaching. In order to achieve success in this field, it is essential to love teaching. Success of students in education is not only related to curriculum or materials-equipment. It is also important to have knowledgeable, experienced and wellequipped teachers (Başal and Taner, 2004).

Primary duties of the individual in the teaching profession are to work willingly, to have patience, effort and work (Aşkar and Erden, 1987). Here, the attitudes of the students who study for being teachers towards teaching become very important. As a matter of fact, if this profession is done with love and will, new generations will respect and protect the teaching profession. "As stated by our Great Leader, in line with the General Purpose and Basic Principles of Turkish National Education System, the most important task in bringing up students who are curious, innovative and capable of team work and in implementation of developed teaching programs in an active and effective way belongs to teachers" (Ministry of National Education, 2008). Today, it would positively contribute to their development thanks to practice teachers who conduct their duties, perform their job correctly and can be role models in selection of competent candidate teachers and assignment of them to classrooms (Çevik and Alat, 2012). At the same time, it is known that candidate teachers contribute to one in-service development of practice teachers. Candidate teachers benefiting from this experience and knowledge also take the opportunity to ensure improvement in their own professional competence (Kiraz, 2001). Education is one of the important factors for the development of societies and individuals and the teachers working in this field are also as important as education. In addition, teachers have become an indispensable part of the education system as those who make the behaviors of the students, and ensure to develop and change these behaviors. Therefore, the success in the education system cannot be separated from the success of the teacher. Undoubtfully, this success also will depend on teachers being adequate in their fields (Ipek, 2015). In this sense, teacher's self-efficacy affects the success state in teaching profession, which indirectly affects the success in the success level in the provided education.

Today, teachers must leave the old system behind and emphasize the new and innovation. There are certain expectations for these innovations such as working hard, using knowledge well, having teaching skills and providing the skill to interpret with different points of view (Erişen and Celiköz, 2003). In these terms, teachers must have sufficient knowledge and experience in their fields. Despite all of these competences are available, our country has not trained sufficient number of competent teachers yet (Demir, 1997). In order to train sufficient number of competent teachers, it is of great importance that planning of our education system is conducted by experts who are sufficiently well-equipped in this field. Increase of society's expectations towards education and teachers has also made the teachers' tasks increase. Rapidly developing technology also changes the running of the curriculum in the system. It must be the national policy to train skillful and unique teachers who are ready for this change and development (Temizkan, 2008). 


\section{Method}

The data collected within the research were analyzed using SPSS 22 software. Before analyzing the data, reliability and normality tests were conducted for both scales. As a result of the analyzes conducted, it was found that the reliability level of the attitude scale was, 924, the perception scale was ,969, and both scales did not show normal distribution. Therefore, non-parametric analyzes were applied. Mann Whitney U test was used to compare scale scores of university students participating in the study according to gender, academic success level and sports activities while Kruskal Wallis H test was used to compare scale scores according to their age groups, universities, departments and income status. Spearman Correlation analysis was used to examine the relationship between students' self-competence perception and their attitudes towards teaching profession.

\begin{tabular}{c|c|c|c} 
Table-1. Averages of university students' in relation to their attitude towards teaching profession and their self-competence perceptions. \\
\hline Scale & $\mathbf{N}$ & $\mathbf{X}$ & Sd \\
\hline Approach & 299 & 3,98 &, 760 \\
\hline Perception & 299 & 4,11 &, 675 \\
\hline
\end{tabular}

Upon examination of the table, it is observed that averages of university students participating in the study in relation to their attitude towards teaching profession and their self-competence perceptions are over average level and close to high.

Table-2. Comparison of university students' in relation to their attitude towards teaching profession and their self-competence perceptions based on their universities.

\begin{tabular}{|c|c|c|c|c|c|c|c|}
\hline Scale & University & $\mathbf{N}$ & $\mathbf{X}$ & Sd & Mean rank & $\mathrm{x}^{2}$ & $\mathbf{P}$ \\
\hline \multirow{3}{*}{ Approach } & Çukurova & 39 & 4,25 & ,671 & 179,85 & \multirow{3}{*}{6,735} & \multirow{3}{*}{,034 } \\
\hline & Mustafa Kemal & 226 & 3,92 &, 774 & 143,08 & & \\
\hline & Sütçü İmam & 34 & 4,09 & ,701 & 161,79 & & \\
\hline \multirow{3}{*}{ Perception } & Çukurova & 39 & 4,10 &, 685 & 151,42 & \multirow{3}{*}{, 437} & \multirow{3}{*}{,804 } \\
\hline & Mustafa Kemal & 226 & 4,09 &, 702 & 148,43 & & \\
\hline & Sütçü İmam & 34 & 4,24 & , 447 & 158,79 & & \\
\hline
\end{tabular}

Dependent variable: Self-efficacy

Upon examination of the table, it is observed that the level of self-competence perception of the university students participating in the study did not differ statistically significantly ( $p>0,05)$, and their attitude levels related to teaching profession differed statistically significantly based on the universities they studied $(\mathrm{p}<0,05)$. In the attitude towards teaching profession, the attitude level of students studying at Çukurova University is statistically significantly higher than the attitude level of students studying at Mustafa Kemal University $(\mathrm{p}<0,05)$.

Table-3. Comparison of university students' in relation to their attitude towards teaching profession and their self-competence perceptions based on their academic success levels.

\begin{tabular}{|c|c|c|c|c|c|c|c|c|}
\hline Scale & Academic success & $\mathbf{N}$ & $\mathbf{X}$ & Sd & Mean rank & Total rank & $\mathbf{U}$ & $\mathbf{P}$ \\
\hline \multirow{2}{*}{ Attitude } & Average & 199 & 3,96 &, 747 & 146,80 & 29214,0 & \multirow{2}{*}{9314,0} & \multirow{2}{*}{, 367} \\
\hline & High & 100 & 4,03 &, 787 & 156,36 & 15636,0 & & \\
\hline \multirow{2}{*}{ Perception } & Average & 199 & 4,03 & ,659 & 136,58 & 27179,5 & \multirow{2}{*}{7279,5} & \multirow{2}{*}{,OO0 } \\
\hline & High & 100 & 4,26 & ,684 & 176,71 & 17670,5 & & \\
\hline
\end{tabular}

Dependent variable: Self-efficacy

Upon examination of the table, it is observed that attitude levels related to teaching profession of the university students participating in the study did not differ statistically significantly $(p>0,05)$, and their level of selfcompetence perception differed statistically significantly based on the their academic success levels $(p<0,05)$. Selfcompetence perceptions of students who have higher academic success levels are higher compared to students with lower academic success levels.

Table-4. Comparison of university students' in relation to their attitude towards teaching profession and their self-competence perceptions based on their sports habits.

\begin{tabular}{c|c|c|c|c|c|c|c|c|c}
\hline Scale & Sports habits & N & X & Sd & Mean rank & Total rank & U & P \\
\hline \multirow{2}{*}{ Attitude } & Yes & 231 & 3,97 &, 783 & 149,48 & 34529,0 & \multirow{2}{*}{7733,0} & \multirow{2}{*}{, 847} \\
\cline { 2 - 9 } & No & 68 & 4,02 &, 683 & 151,78 & 10321,0 & \\
\hline \multirow{2}{*}{ Perception } & Yes & 231 & 4,07 &, 708 & 146,06 & 33740,5 & \multirow{2}{*}{6944,5} & \multirow{2}{*}{, 147} \\
\cline { 2 - 9 } & No & 68 & 4,25 &, 530 & 163,38 & 11109,5 & \\
\hline
\end{tabular}

Dependent variable: Self-efficacy

Table-5. Comparison of university students' in relation to their attitude towards teaching profession and their self-competence perceptions based on their income levels.

\begin{tabular}{|c|c|c|c|c|c|c|c|}
\hline Scale & Income level & $\mathbf{N}$ & $\mathbf{X}$ & Sd & Mean rank & $\mathrm{x}^{2}$ & $\mathbf{P}$ \\
\hline \multirow{4}{*}{ Attitude } & Low & 38 & 3,82 & ,786 & 132,12 & \multirow{4}{*}{12,101} & \multirow{4}{*}{,007 } \\
\hline & Average & 223 & 4,06 & ,729 & 158,98 & & \\
\hline & High & 26 & 3,53 & ,837 & 102,06 & & \\
\hline & Very High & 12 & 3,96 & ,759 & 143,58 & & \\
\hline \multirow{4}{*}{ Perception } & Low & 38 & 4,10 & ,683 & 149,61 & \multirow{4}{*}{1,243} & \multirow{4}{*}{, 743} \\
\hline & Average & 223 & 4,13 & ,667 & 151,63 & & \\
\hline & High & 26 & 4,09 & ,706 & 149,04 & & \\
\hline & Very High & 12 & 3,90 &, 778 & 123,13 & & \\
\hline
\end{tabular}

Dependent variable: Self-efficacy 
Upon examination of the table, it is observed that attitude levels related to teaching profession of the university students participating in the study and their level of self-competence perception did not differ statistically significantly based on their sports habits $(p>0,05)$.

Upon examination of the table, it is observed that the level of self-competence perception of the university students participating in the study did not differ statistically significantly ( $p>0,05)$, and their attitude levels related to teaching profession differed statistically significantly based on their income levels $(p<0,05)$. In the attitude towards teaching profession, the attitude level of students with average income levels are statistically significantly higher than the attitude level of students with higher income levels $(\mathrm{p}<0,05)$.

\section{Discussion and Conclusion}

Upon examination of Table 1 it is observed that attitude levels related to teaching profession of the university students participating in the study and their level of self-competence perception are above average level and close to high. Upon examination of Table 2 it observed that the level of self-competence perception of the university students participating in the study did not differ statistically significantly, and their attitude levels related to teaching profession differed statistically significantly based on the universities they. In the attitude towards teaching profession, the attitude level of students studying at Çukurova University is statistically significantly higher than the attitude level of students studying at Mustafa Kemal University. This condition can be interpreted that that different schools of university students affect their attitude towards teaching profession while it does not effect their self-competence perception levels. In this context, when we examine the attitudes related to teaching profession, it is seen that as a result of the study of Semerci and Semerci (2004) who obtained results contrary to our study that there is no statistically significant difference based on universities in terms of attitude towards teaching profession in their study conducted with candidate teachers studying in physical education and sports teaching bachelor's degree programs in different universities. In another study, Koçak Macun et al. (2019) did not find any significant difference between teacher candidates' self-efficacy levels and their readiness level for business life according to the department they have studied. In the study of Güleçen et al. (2008) who obtained similar results, it was observed that there is no statistically significant difference in students' attitude towards teaching profession based on their universities while it was found that professional attitudes did not differ based on the graduation faculty variable in the study of Yllmaz (2009) conducted with preschool candidate teachers and in the study of Orhan (2013) where they examined professional attitudes and job satisfaction levels of candidate teachers. When we examine the self-competence perception results of university students participating in the study, (Ozdemir, 2008) obtained results in the same direction with ours as it found no statistically significant difference in self-competence perceptions of candidate teachers in relation to certain dimensions of teaching process based on the university variable while Gençtürk (2008) and Türk (2008) who obtained similar results in their studies conducted with teachers found no statistically significant difference in self-competence perceptions of teachers based on the schools they graduated. In Yildirım (2011) study conducted with form teachers, it was observed that there was no statistically significant difference in terms of current university variable. As a matter of fact, Akbaş and Celikkaleli (2006) who obtained results different from our study found in their study conduced in order to determine selfcompetence perceptions of form teacher candidates in terms of science teaching that self-competence perceptions and result expectations of form teacher candidates differed based on their universities while Zararsiz (2012) found in their study conducted in order to determine self-competence perceptions of teachers working at elementary schools in Sultanbeyli district of Istanbul that there was a statistically significant difference in terms of faculty graduated variable. In his study, Köksoy (2017) also argued that the school environment and teachers are present in the development of self-efficacy. Upon examination of Table 3 it is observed that attitude levels related to teaching profession of the university students participating in the study did not differ statistically significantly, their level of self-competence perception differed statistically significantly based on the their academic success levels, and that self-competence perceptions of students who have higher academic success levels are higher compared to students with lower academic success levels. In other words, it can be interpreted that self-competence perception levels of successful university students in relation to teaching profession is higher.

Upon relevant literature review, it was found that Akbaba (2013) in their study similar to ours as conducted with office management teacher candidates determined that self-competence perception levels of teacher candidates statistically significantly differed based on general academic success level while Alabay (2006), Calışkan et al. (2010), Derman (2007), Yenilmez and Kakmacı (2008) revealed that self-competence perceptions of candidate teachers significantly differed based on academic success variable. Self-competence is a concept related to the confidence of teacher candidates towards their cognitive skills of learning or achieving an academic task. Therefore, this sense of confidence directly affects the learners' activity preferences, efforts and success status. There are findings that there is a positive relation between academic self-competence and success (Schunk, 1995; Pajares, 1996; Bandura, 1997). Schunk and Pajares (2002) stated that there is a relation between academic self-competence and self-regulation capacity and effective learning strategies, and that academic self-competence predicts academic success with these variables. In many researches conducted, it was found that self-competence perception is a significant predictor of academic success (Uredi and Uredi, 2006). However, it is seen in studies of Demirel and Akkoyunlu (2010) and Oğuz (2009) that general academic success did not affect self-competence perceptions of teachers while Yağcl and Aksoy (2015) revealed in their studies that there is no significant relation between academic GPAs and teachers' self-competence perceptions. Yıldırım (2011), Bayrakdar et al. (2016) and Soysal (2014) studies towards teacher candidates where they obtained similar results shown that self-competence perceptions of teacher candidates did not significantly differ based on academic success levels. Karabulut et al. (2019) concluded that academic success did not affect teacher candiates' perceptions for themselves. When we examine the levels of attitude towards teaching profession, it was seen in Ciğdem (2010) study titled examination of attitudes of form teacher candidates towards learning styles and teaching profession in terms of various variables where contrary findings were obtained that statistically significant difference was found based on academic success level while similarly (Sandıkçı, 2011) in their study examining the attitude and self-competence perceptions of physical education teacher candidates and other teacher candidates towards teaching profession shown statistical 
difference based on academic success variables. Upon examination of Table 4 it is observed that attitude levels related to teaching profession of the university students participating in the study and their level of selfcompetence perception did not differ statistically significantly based on their sports habits.

On the other hands, it can be said that sports habits of university students do not affect their attitude towards teaching profession and their self-competence perception levels. In another study made, the attitudes of Altuntaş (2016) research group towards teaching profession did not reach a meaningful difference according to sporting status. Considering the attitudes of university students participating in the study towards teaching profession, Eroğlu (2011) obtained results in a different direction and found in their study conducted with physical education teacher candidates that their professional attitudes differed based on their sports habits while Kafkas et al. (2010) in their study found that it statistically differed in favor of teacher candidates answering yes based on licensed sports habits variable. In the study of Unlü (2008) who obtained similar results, there were significant differences in "program and content knowledge", "learning and teaching process", "knowing the student", "school-family and society relations", "personal and professional development" competence fields based on regular sports habits variable of physical education teachers while it was found that competence scores of physical education teachers who regularly exercise sports are higher than the ones who do not. In addition, it was stated that physical education teachers who were former licensed athletes considered themselves more competent. As a matter of fact, (Küçük Kılıç, 2014) who obtained results similar to our study stated as a result of their research that professional attitude of teacher candidates did not statistically significantly differ based on active sports variable. When selfcompetence perceptions of university students are reviewed, Unlü (2008) found significant differences in competence fields except monitoring and assessment of learning when competence perceptions towards teaching profession is considered based on regular sports habit of physical education teachers.

Research results of Denham and Michael (1981) related to sports performances and competencies of physical education teachers supported the results of this research. According to Denham and Michael (1981) it was seen that teachers who have high levels of competence perception attributed their own successful performances to the activities they perform. Zülkadiroğlu et al. (2007) stated that positive effects of various factors towards selfcompetence perceptions of individuals can be observed indirectly, however absolute effects of sports and physical activities on self-competence can be observed clearly. Researches emphasize that participation in sports and physical activities have positive effects on individuals' self-competence perceptions. Upon examination of Table 5 it is observed that the level of self-competence perception of the university students participating in the study did not differ statistically significantly, and their attitude levels related to teaching profession differed statistically significantly based on their income levels. In the attitude towards teaching profession, the attitude level of students with average income levels are statistically significantly higher than the attitude level of students with higher income levels. This condition can be interpreted that while the income levels of university students participating in the study do not serve for self-competence perceptions, it is also seen that it has a positive effect on their attitude levels towards the profession. When we conduct a relevant field review in the light of these findings, it was found that Celiköz (2010) who obtained results contained to our study found in their study examining attitudes of clothing teacher candidates towards teaching profession in terms of certain variables that the attitude towards teaching profession did not differ based on monthly income variable. Eş (2010) who obtained similar results with Çeliköz, stated in their study conduced with form teacher candidates that monthly income status did not differ while in the study conducted by Ekici (2005) it was found that there was no difference in terms of income levels of families which is a different variable. As a matter of fact, Akbaş (2008) stated in their study conducted with teachers working at vocational high schools stated that there is no significant difference between the attitude towards teaching and income level variables. Karahan (2005) who obtained similar results with our study, found in their study that there is a statistically significant difference in terms of attitudes towards teaching profession based on monthly income levels of individuals.

When we review the self-competence perceptions of university students, Berkant (2017) who obtained similar results with our study found that monthly income level did not affect self-competence perceptions of teachers in their study where self-competence perceptions of teacher candidates are examined.

\section{References}

Akbaba, D., 2013. Investigation of teacher self-efficacy perceptions of office management teachers in terms of some variables. Gazi University Institute of Educational Sciences, Master's Thesis.

Akbaş, A. and Ö. Celikkaleli, 2006. Investigation of elementary school class teacher candidates' self-efficacy beliefs in science teaching according to gender, education type and university. Mersin University Journal of Faculty of Education, 1(2): 98-110.

Akbaş, M., 2008. The relationship between marital adjustment and teaching attitudes of teachers working in industrial vocational high schools. Master's Thesis, Yeditepe University, Institute of Social Sciences, Istanbul.

Alabay, E., 2006. Investigation of science-related self-efficacy belief levels of elementary school preschool teacher candidates. Yedi Tepe University Journal of Faculty of Education, 2(1): 30-40.

Altuntaş, E.A., 2016. The relationship between attitudes of physical education teacher candidates related to teaching profession and their self-efficacy. International Journal of Contemporary Educational Studies, 2(2): 196-215.

Aşkar, P. and M. Erden, 1987. Teacher candidates' attitudes towards profession. The Journal of Modern Education, 121: 8-11.

Atmaca, H., 2015. Investigation of the attitudes of foreign language teacher candidates about teaching profession. Uludağ University Journal of Faculty of Education, 28: 401-405.

Bandura, A., 1997. Self-efficacy: The exercise of control. New York: Freeman.

Başal, H., A. and M. Taner, 2004. The relationship between the academic achievements of preschool education students and the type of their high school and graduation degrees. OMEP World Council Meeting and Conference. 8-11 October 2003 Kuşadası/Turkey, Proceedings book: Ya-Pa Publishing. Istanbul. 2, 482-489.

Bayrakdar, U., B.M. Vural and Y. Barut, 2016. Teacher self-efficacy levels and attitudes towards teaching profession of special education teacher candidates. Journal of Kirsehir Education Faculty 17(2): 133-149.

Berkant, G., H., 2017. Investigation of teacher self-efficacy perceptions of teacher candidates. The Journal Of Educational Reflections, 1(2): 117.

Calışkan, S., G. Selçuk and Ö. Özcan, 2010. Self-efficacy beliefs of physics student teachers': Effects of gender, class level and academic achievement. Kastamonu Education Journal, 18(2): 449-466.

Celiköz, M., 2010. Investigation of attitudes of clothing teacher candidates towards teaching profession in terms of some variables. Selçuk University Institute of Social Sciences, Master's Thesis, Konya. 
Celiköz, N. and F. Cetin, 2004. Factors affecting the attitudes of AOL (open education high school) students towards teaching profession. Journal of National Education, 32(162): 136-145.

Cetin, F., 2006. Developing the teaching profession attitude scale (validity and reliability study). Gazi University Journal of Faculty of Industrial Arts Education, 18(1): 28-37.

Çevik, C. and K. Alat, 2012. Developing attitude scale towards teaching practice course of practice teachers. Uluda $\breve{g}$ University The Journal of Faculty of Education, 25(2): 359-380.

Ciğdem, G., 2010. Investigation of elementary school teacher candidates' learning styles and attitudes towards teaching profession in terms of various variables. Zonguldak Karaelmas University Institute of Social Sciences, Master's Thesis, Zonguldak.

Demir, M., C., 1997. Comparison of teacher training practices in france and Turkey. Master's Thesis, Balıkesir University Institute of Social Sciences, Balıkesir.

Demirel, M. and B. Akkoyunlu, 2010. Evaluation teacher candidates' self-efficacy beliefs and learning styles in science and technology teaching international teacher training policies and problems symposium II, Mayıs, Ankara: Hacettepe University. pp: 16-18.

Demirtaş, H., M. Cömert and N. Özer, 2011. Teacher candidates' self-efficacy beliefs and their attitudes towards teaching profession. The Journal of Education and Science, 36(159): 96-111.

Denham, C.H. and J.J. Michael, 1981. Teacher sense of efficacy: A definition of the construct and a model for further research. Educational Research Quarterly, 6(1): 39-63.

Derman, A., 2007. Self-efficacy perceptions of Chemistry teacher candidates and their attitudes towards teaching profession, Doctoral Thesis, Selçuk University, Konya.

Duymaz, R., 2007. Idealist teacher. Istanbul: 3f Publications.

Ekici, G., 2005. Faculty of education factors affecting students' self-efficacy beliefs for Teaching. XIV. National Congress of Educational Sciences Pamukkale University Faculty of Education, 28-30 Eylül. pp: 811-815.

Erişen, Y. and N. Celiköz, 2003. Teacher candidates' perceptions of self-efficacy towards theirselves in terms of general teaching behavior. Journal of Turkish Educational Sciences, 1(4): 427-439.

Eroğlu, B., 2011. The effects of teaching practice on professional competence and attitudes towards profession of physical education teacher candidates. Gazi University Institute of Educational Sciences, Master's Thesis, Ankara.

Eş, U., 2010. Investigation of elementary school teacher candidates' attitudes towards teaching profession and reasons for choosing the teaching profession. Niğde University Institute of Social Sciences, Master's Thesis, Niğde.

Gençtürk, A., 2008. Investigation of elementary school teachers' self-efficacy perceptions and job satisfaction in terms of various variables. Master's Thesis. Zonguldak University of Technology, Zonguldak.

Güleçen, S., E. Cüro and N. Semerci, 2008. Attitudes of anatolian teacher high school students about teaching profession. Fırat University Journal of Social Sciences, 18(1): 139-157.

Ipek, S., 2015. Classroom management self-efficacy beliefs and professional attitudes of teachers working in elementary schools (sample case of rize province). Master's Thesis. Avrasya University, Institute of Social Sciences, Rize.

Kafkas, M.E., M. Açak, B. Çoban and T. Karademir, 2010. The relationship between self-efficacy perceptions and professional concerns of physical education teacher candidates. Inönü University Journal of Faculty of Education, 11(2): 93-111.

Kağıtçıbaşı, C., 2010. People and people at the present time: Introduction to social psychology. Istanbul: Evrim Publications.

Karabulut, A., A. Yandı and A. Kaya, 2019. Determination of self-efficacy beliefs of teacher candidates studying in special education department. Turkish Social Surveys Journal, 23(2): 555-574.

Karahan, H., 2005. Investigation of geography teachers working in secondary education institutions with other teachers in terms of teaching attitudes. Master's Thesis, Marmara University Institute of Educational Sciences, Istanbul.

Kiraz, E., 2001. Candidate teacher-advisory teacher interaction: Other dimension in professional development. Journal of Educational Researches, 1(5): 85-92.

Koçak Macun, B., B. Macun and S. S., 2019. Investigation of teacher self-efficacy belief levels and business-life-readyness of teacher candidates. International Journal of Turkish Literature Culture Education, 8(1): 549-567.

Köksoy, M.A., 2017. Investigation of music teaching self-efficacy levels of elementary school class teacher candidates. Mehmet Akif Ersoy University Journal of Faculty of Education, 44: 297-332.

Koyuncu, Ş.M., 2015. Investigation of self-confidence and professional attitudes of preschool teachers. Master's Thesis. Afyon Kocatepe University Institute of Social Sciences, Afyon.

Küçük Kılıç, S., 2014. Physical education teacher candidates' metacognitive learning strategies, academic self-efficacy and attitudes towards teaching profession. Karadeniz Teknik University Institute of Educational Sciences, Master's Thesis, Trabzon.

Küçükahmet, L., 2003. Introduction to teaching profession. Ankara: Nobel Publishing Distribution.

Ministry of National Education, 2008. Teacher competencies, general and special field competencies of teaching profession. Ministry of National Education, Ankara.

Oğuz, A., 2009. Investigation of teacher self-efficacy beliefs of candidate teachers. Dumlupınar University Journal of Social Sciences, 24(1): 281-290.

Orhan, N., 2013. Professional attitudes and job satisfaction levels of candidate teachers. Dokuz Eylül University Institute of Educational Sciences, Master's Thesis, İzmir.

Ozdemir, S., 2008. Investigation of self-efficacy beliefs of elementary school teacher candidates with respect to teaching process in terms of various variables. Educational Administration in Theory and Practice, 54: 277-306.

Pajares, F., 1996. Self-efficacy beliefs in academic settings. Review of Educational Research, 66(4): 543-578.Available at: https://doi.org/10.3102/00346543066004543.

Sağlam, Ç.A., 2008. Attitudes of students of music teaching department towards teaching profession. Yüzüncü Yıl University, Journal of Faculty of Education, 5(1): 59-69.

Şahin, A., E., 2007. Teaching as a profession. V. Sönmez (Ed) Introduction to teaching science, Ankara: Anı Publishing.

Sandıkçı, M., 2011. Attitudes and self-efficacy perceptions of physical education teacher candidates and other teacher candidates with respect to teaching profession. Karadeniz Teknik University Institute of Educational Sciences, Master's Thesis, Trabzon.

Schunk, D., H., 1995. Self-efficacy and education and instruction. In J. E. Maddux (Ed.), Self-efficacy, adaptation, and adjustment: Theory, research, and application. New York: Plenum Press. pp: 281- 303.

Schunk, D.H. and F. Pajares, 2002. The development of academic self-efficacy. In a. Wigfield, J.S. Eccles. Development and achievement motivation. California: Academic Press.

Semerci, N. and Ç. Semerci, 2004. Attitudes of teaching in Turkey. Firat University Journal of Social Sciences, 14(1): 137-146.

Sişman, M., 2004. Introduction to teaching. Ankara: Pegem Publishing.

Soysal, M.R., 2014. Self-efficacy beliefs of primary school teacher education students. Abant İzzet Baysal University Institute of Education Sciences, Master's Thesis, Bolu.

Temizkan, M., 2008. An evaluation on the attitudes of Turkish teacher candidates their professions. Turkish Journal of Educational Sciences, 6(3): 461-486.Available at: https://doi.org/10.7827/turkishstudies.2826.

Türk, Ö., 2008. Examination of self-efficacy and professional satisfaction of elementary school teachers. Master's Thesis. Yeditepe University, Istanbul.

Unlü, H., 2008. Physical education teachers' competencies and classroom management behaviors. Doctoral Thesis, Gazi University Institute of Educational Sciences, Ankara.

Uredi, I. and L. Uredi, 2006. Comparison of self-efficacy beliefs of elementary school teachers related to science teaching according to their gender, classes and success levels. Yeditepe University Journal of Faculty of Education, 1(2): 83-92.

Yağcl, U. and V. Aksoy, 2015. Investigation of the relationship between academic self-efficacy and teaching self-efficacy of music teacher candidates. Mehmet Akif Ersoy University Journal of Faculty of Education, 33: 89 - 104.

Yenilmez, K. and Ö. Kakmacı, 2008. Self-efficacy belief levels of students of elementary school Mathematics teaching department. Eskisehir Osmangazi University Journal of Social Sciences, 9(2): 1-22. 
Ylldırım, A., 2011. Investigation of the relationship between self-efficacy perceptions and professional concern levels of elementary school teachers' Marmara University Institute of Educational Sciences, Master's Thesis, Istanbul.

Yılmaz, S.Ş., 2009. Investigation of the relationship between professional attitudes and personal values of preschool teacher candidates. Abant İzzet Baysal University Institute of Social Sciences. Master's Thesis, Bolu.

Zararsız, N., 2012. Investigation of self-efficacy perceptions of teachers working in elementary schools. Abant Izzet Baysal University Institute of Educational Sciences, Master's Thesis, Bolu.

Zülkadiroğlu, Z.F., D. Bostan Budak and E. Kozanoğlu, 2007. Importance of competence expectation in sport and physical activity. Spormetre-the Journal of Physical Education And Sport Sciences, 5(1): 9- 15. 